\title{
METODE TOTAL PHYSICAL RESPONSE (TPR) UNTUK PENGEMBANGAN KEMAMPUAN MENDENGARKAN DALAM PEMBELAJARAN BAHASA INGGRIS BAGI ANAK USIA DINI
}

\author{
Oleh \\ Ni Wayan Satri Adnyani \\ Institut Hindu Dharma Negeri Denpasar \\ satri.adnyani@gmail.com
}

\begin{abstract}
Early age is the golden age for children to learn language, without neglecting the development of other aspects that are very important in their lives. Language and communication skills are a necessity and essential for the beginning of the process at school. Listening skills are the first and most basic skills developed by language learners, both in learning first language, second language and foreign languages. The TPR method can motivate children to be interested in learning English, especially training in listening skills because this method is very comforting for them in following the learning process in the classroom and helping early childhood understanding of effective English learning. Some techniques or activities that can be used to train early childhood abilities in listening to English are imperative drill, action songs and using flash cards.
\end{abstract}

Key words : Total Physical Response, Listening Skill, Early Childhood Education

\begin{abstract}
ABSTRAK
Usia dini merupakan usia emas bagi anak untuk belajar bahasa, tanpa mengabaikan perkembangan aspek-aspek lainnya yang sangat penting dalam kehidupannya. Kemampuan berbahasa dan berkomunikasi merupakan kebutuhan dan merupakan hal esensial untuk awal proses di sekolah. Keterampilan mendengarkan adalah keterampilan pertama dan paling dasar yang dikembangkan oleh pembelajar bahasa, baik dalam belajar bahasa pertama, bahasa kedua maupun bahasa asing. Metode TPR dapat memotivasi anak untuk tertarik belajar bahasa Inggris terutama melatih kemampuan mendengar (listening) karena metode ini sangat menghibur mereka dalam mengikuti proses pembelajaran di kelas dan membantu pemahaman anak usia dini terhadap pembelajaran bahasa Inggris secara efektif. Beberapa teknik atau aktivitas yang dapat digunakan untuk melatih kemampuan anak usia dini dalam mendengarkan bahasa Inggris yaitu imperative drill, action songs dan using flash cards.
\end{abstract}

Kata kunci : Total Physical Response, Kemampuan Mendengarkan, Pendidilan Anak Usia Dini

\section{PENDAHULUAN}

Banyak aspek yang mempengaruhi perkembangan seorang anak, aspek-aspek tersebut memberikan kontribusi besar terhadap perkembangan anak, antara lain perkembangan motorik, kognitif, sosial, fisik, emosi serta perkembangan bahasa. Bahasa merupakan aspek penting dalam perkembangan pada masa bayi dan anakanak. Menguasai bahasa memungkinkan 
anak untuk dapat berinteraksi dengan lingkungannya secara efektif. Suhartono (2005:8) menyatakan bahwa dengan menggunakan bahasa, anak akan dapat tumbuh dan berkembang menjadi manusia dewasa yang dapat bergaul di tengah-tengah masyarakat. Khususnya pada anak usia dini, kemampuan berbahasa dan berkomunikasi merupakan kebutuhan dan merupakan hal esensional untuk awal proses di sekolah. Anak usia 4-5 tahun berada pada tahap pra operasional, yang mana pada tahap ini anak mulai mengembangkan kemampuan berbahasanya. Pemerolehan bahasa pada anak usia dini meliputi 2 tahapan yaitu pemerolehan bahasa pertama dan pemerolehan bahasa kedua (bahasa asing). Bahasa pertama sering disebut juga bahasa ibu, karena anak pertama kali berinteraksi dan belajar dengan ibu (bahasa yang dipakai dalam keluarga). Sedangkan bahasa kedua adalah bahasa anak yang diperoleh setelah bahasa pertama. Bahasa kedua anak di Indonesia pada umumnya bahasa Indonesia dan asing (bahasa Inggris).

Persaingan kerja di era globalisasi saat ini menuntut masyarakat untuk menguasai bahasa Inggris baik secara lisan maupun tulisan. Tuntutan tersebut membuat para orang tua berlomba-lomba memasukkan anak mereka ke sekolah yang bertaraf internasional ataupun nasional plus dimana media bahasa yang digunakan adalah bahasa Inggris.

Maraknya pembelajaran bahasa Inggris pada pendidikan tingkat dasar direspon sangat baik oleh masyarakat (Yauri, 2007). Hal ini karena bahasa Inggris memiliki peranan penting, tidak hanya sebagai bahasa akademis tetapi juga sebagai bahasa seharihari, seperti yang digunakan dalam computer, internet, perbankan, medis, pariwisata, penerbangan, hiburan dan radio. Lebih jauh lagi, Nunan (2003) menyatakan bahwa dalam dunia usaha, industri, dan pemerintahan, para pekerja diharapkan segera meningkatkan kemampuan bahasa Inggrisnya. Karenanya, para orang tua menginginkan anak-anaknya mendapatkan pengajaran bahasa Inggris sedini mugkin guna memperoleh manfaat untuk kepentingan akademik dan karier usaha di masa depan (Sad, 2010).
Menurut Shin (2006), mengajar bahasa Inggris kepada anak- anak memang berbeda dengan kepada orang dewasa karena mereka suka bergerak dan terlibat dalam partisipasi fisik. Menurutnya, semakin merasa senang, semakin baik mereka mengingat bahasa yang dipelajarinya. Selain itu, Scott dan Ytreberg (1990) menekankan bahwa, anak dapat memahami sesuatu melalui tangan, mata dan telinga, dan kegiatan fisik mendominasi setiap saat. Berdasarkan hal tersebut, maka salah satu metode pengajaran yang cocok digunakan oleh para guru untuk mengajarkan bahasa Inggris bagi anak usia dini adalah metode Total Physical Response (TPR).

\section{PEMBAHASAN \\ 2.1 Bahasa Inggris untuk Anak Usia \\ Dini}

Usia dini merupakan usia emas bagi anak untuk belajar bahasa, tanpa mengabaikan perkembangan aspek-aspek lainnya yang sangat penting dalam kehidupannya. Pembelajaran bahasa asing pada anak usia dini di bawah 6 tahun dilakukan sebagai perkenalan bahasa bukan sebagai hal yang utama. Menurut Christina (2010) bahwa anakanak usia 3-6 tahun paling cepat memahami bahasa Inggris, apabila mereka dibiasakan untuk mengungkapkan kata atau ungkapan dalam bahasa Inggris. Permasalahan yang sering ditemukan di lapangan adalah anak - anak mengalami kesulitan dalam memahami bahasa Inggris karena kurangnya perbendaharaan kata anak dalam mengenal bahasa Inggris. Maka, sangat penting untuk menciptakan suasana nyaman, agar anak tidak merasa bosan dan jenuh pada waktu melaksanakan kegiatan, dan agar anak senang belajar bahasa Inggris pada masa yang akan datang mengingat bahasa Inggris merupakan bahasa Internasional.

Menurut Piaget, anak pada usia $2-7$ tahun sedang dalam tahap praoperasional stage, yaitu tahap yang mempunyai ciri pokok perkembangannya menggunakan simbol/ bahasa tanda dan konsep intuitif. Tahap ini dibagi menjadi dua tahap, yaitu tahap pertama tahap pra konseptual (2-4 tahun), dimana representasi suatu objek dinyatakan dengan bahasa, gambar dan permainan khayalan. 
Kedua, tahap intuitif (4-7 tahun). Pada tahap ini representasi suatu objek didasarkan pada persepsi pengalaman sendiri, tidak kepada penalaran. Istilah "operasi" di sini adalah suatu proses berfikir logis, dan merupakan aktivitas sensorimotor. Dalam tahap ini anak sangat egosentris, mereka sulit menerima pendapat orang lain. Anak percaya bahwa apa yang mereka pikirkan dan alami juga menjadi pikiran dan pengalaman orang lain. Mereka percaya bahwa benda yang tidak bernyawa mempunyai sifat bernyawa. Karakteristik anak pada tahap ini adalah sebagai berikut:

a) Anak dapat mengaitkan pengalaman yang ada di lingkungan bermainnya dengan pengalaman pribadinya, dan karenanya ia menjadi egois. Anak tidak rela bila barang miliknya dipegang oleh orang lain.

b) Anak belum memiliki kemampuan untuk memecahkan masalah-masalah yang membutuhkan pemikiran "yang dapat dibalik (reversible)." Pikiran mereka masih bersifat irreversible.

c) Anak belum mampu melihat dua aspek dari satu objek atau situasi sekaligus, dan belum mampu bernalar (reasoning) secara individu dan deduktif.

d) Anak bernalar secara transduktif (dari khusus ke khusus). Anak juga belum mampu membedakan antara fakta dan fantasi. Kadang-kadang anak seperti berbohong. Ini terjadi karena anak belum mampu memisahkan kejadian sebenarnya dengan imajinasi mereka.

e) Anak belum memiliki konsep kekekalan (kuantitas, materi, luas, berat dan isi).

f) Menjelang akhir tahap ini, anak mampu memberi alasan mengenai apa yang mereka percayai. Anak dapat mengklasifikasikan objek ke dalam kelompok yang hanya mempunyai satu sifat tertentu dan telah mulai mengerti konsep yang konkrit.

Jadi, apabila anak usia dini belajar bahasa Inggris mereka sedang dalam tahap praoperational stage dan oleh karena itu mereka memerlukan banyak ilustrasi, model, gambar, dan kegiatan-kegiatan lain.

Periode paling sensitif terhadap bahasa dalam kehidupan seseorang adalah antara umur dua sampai tujuh tahun. Segala macam aspek dalam berbahasa harus diperkenalkan kepada anak sebelum masa sensitif ini berakhir. Pada periode sensitif ini sangat penting diperkenalkan cara berbahasa yang baik dan benar, karena keahlian ini sangat berguna untuk berkomunikasi dengan lingkungannya (Maria Montessori,1991).

Berdasarkan teori tersebut maka hal yang tepat jika bahasa Inggris mulai diperkenalkan kepada anak sedini mungkin. Mengingat bahasa Inggris merupakan bahasa asing pertama di Indonesia, maka proses pembelajarannya harus dilakukan secara bertahap. Pemilihan materi yang sesuai dengan usia anak dan juga efektif untuk perkembangan kognitif bahasa anak serta situasi belajar yang menyenangkan haruslah menjadi perhatian utama dalam berhasilnya suatu proses pembelajaran. Keberhasilan proses pembelajaran bahasa Inggris pada anak usia dini tentunya dipengaruhi oleh banyak faktor, antara lain :

1. Guru yang berkualitas, guru yang dapat menghidupkan proses kegiatan belajar mengajar.

2. Sumber dan fasilitas pembelajaran yang memadai dan memenuhi syarat (adekuat).

3. Kurikulum yang baik, sederhana, dan menarik (atraktif).

Di sisi lain perlu dipahami bahwa usia dini adalah usia bermain. Setiap anak adalah pribadi yang unik dan dunia bermain merupakan kegiatan yang serius namun mengasyikan bagi mereka. Maka pendekatan yang tepat perlu diciptakan oleh seorang pendidik agar proses pembelajaran bahasa Inggris lebih menarik dan menyenangkan tanpa meninggalkan kaidah -kaidah bahasa yang benar.

Pendekatan yang digunakan hendaknya sejalan dengan tujuan pengenalan bahasa pada umumnya. Tujuan tersebut ialah supaya anak dapat memahami cara berbahasa yang baik dan benar, berani mengungkapkan ide atau pendapatnya dan dapat berkomunikasi dengan lingkungannya. Dalam pembelajaran bahasa Inggris banyak metode dan teknik yang dapat digunakan, diantaranya melalui Story Telling (Bercerita), Role Play (Bermain Peran), Art 
and Crafts (Seni dan Kerajinan Tangan), Games (Permainan), Show and Tell, Music and Movement (Gerak dan Lagu) dimana termasuk di dalamnya Singing (Nyanyian) dan Chants and Rhymes (Nyanyian Pendek dan Sajak), dan sebagainya.

Metode dan proses pengajaran dalam konteks yang komunikatif meliputi konteks situasi sosial, kultural, permainan, nyanyian dan musik, pembacaan cerita, pengalamanpengalaman kesenian, kerajinan dan mengutamakan gerakan fisik adalah metode yang sangat sesuai dan efektif jika digunakan dalam proses belajar bahasa Inggris khususnya bagi anak usia dini.

Menurut Matondang (2005) musik dan gerak adalah metode yang sangat berhasil jika digunakan dalam proses belajar bahasa Inggris khususnya bagi anak usia dini. Karena pada hakekatnya music (lagu nyanyian) adalah seni menyusun nada atau suara dalam urutan, kombinasi, dan hubungan temporal untuk menghasilkan komposisi yang mempunyai kesatuan dan kesinambungan (mengandung irama). Dan ragam nada atau suara yang berirama disebut juga dengan lagu. Jadi musik ataupun lagu merupakan satu kesatuan yang tidak dapat dipisahkan dan dapat digunakan sebagai sarana dalam sebuah proses pembelajaran.

Sedangkan movement (gerak) yang berarti gerakan, berasal dari kata dasar gerak. Dan 'gerak' memiliki makna, suatu peralihan tempat (adanya aktifitas) yang dilakukan setelah ada dorongan (batin/perasaan). Aktifitas gerakan dapat timbul setelah seseorang mendengarkan lagu/nyanyian. Menggunakan music and movement sebagai pendekatan dalam proses pembelajaran bahasa Inggris dan menyajikannya secara menarik dan menyenangkan dalam sebuah proses kegiatan belajar mengajar, dapat membantu anak untuk lebih senang dan giat belajar serta memudahkan anak untuk memahami suatu materi ajar. Karena dalam melakukan kegiatan belajar anak diajak untuk melakukan dan memperagakan suatu gerakan yang sesuai dengan makna dari lagu yang dinyanyikan.

Jadi gerak dan lagu merupakan suatu aktifitas yang sangat menyenangkan bagi anak dan juga dapat digunakan sebagai motivator di dalam proses belajar bahasa Inggris pada anak usia dini. Music and movement memegang peranan penting dalam proses tumbuh kembangnya seorang anak. Lagu nyanyian dapat memperkaya kehidupan rohani dan memberikan keseimbangan hidup bagi anak. Melalui musik, manusia dapat mengungkapkan pikiran dan perasaan hatinya serta dapat mengendalikan aspek emosionalnya. Adapun nyanyian adalah bagian dari musik. Nyanyian berfungsi sebagai alat untuk mencurahkan pikiran dan perasaan untuk berkomunikasi. Pada hakikatnya nyanyian bagi anak-anak adalah sebagai :

1. Bahasa Emosi, dimana dengan nyanyian anak dapat mengukapkan perasaannya, rasa senang, lucu, kagum, haru.

2. Bahasa Nada, karena nyanyian dapat didengar, dapat dinyanyikan, dan dikomunikasikan.

3. Bahasa Gerak, gerak pada nyanyian tergambar pada birama (gerak/ ketukan yang teratur), pada irama (gerak/ketukan panjang pendek, tidak teratur), dan pada melodi (gerakan tinggi rendah).

\subsection{Keterampilan Mendengarkan dalam Bahasa Inggris}

Keterampilan mendengarkan adalah keterampilan pertama dan paling dasar yang dikembangkan oleh pembelajar bahasa, baik dalam belajar bahasa pertama, bahasa kedua maupun bahasa asing. Melaui keterampilan mendengarkan, siswa dapat memperoleh berbagai input kebahasaan yang menjadi fondasi untuk keterampilan berbahasa selanjutnya, yakni keterampilan berbicara, membaca maupun menulis. Harmer (2007) memaparkan bahwa keterampilan mendengarkan membantu pembelajar bahasa Inggris dalam mengembangkan pelafalan karena kegiatan mendengarkan memberikan kesempatan bagi mereka untuk mendengarkan berbagai tekanan, intonasi, dan bunyi - bunyi bahasa pada kata - kata secara terpisah pisah atau secara keseluruhan dalam sebuah ujaran. Brown (2001) menjelaskan bahwa keterampilan mendengarkan yang baik dapat menjadi fondasi untuk keterampilan 
berbicara. Siswa tidak akan mampu berbicara apabila tidak pernah diekspos dengan kegiatan mendengarkan terlebih dahulu. Melalui aktivitas mendengarkan, mereka dapat belajar menginternalisasi informasi linguistik yang kemudian dapat diaplikasikan dalam kegiatan berbicara.

Machackova (2009:15) menjelaskan lebih rinci bahwa ada beberapa macam kesulitan yang dialami pembelajar dalam kaitannya dengan kemampuan menyimak atau mendengarkan bahasa asing, dalam hal ini terutama bahasa Inggris, yaitu (a). Tidak dapat memahami pengucapan (pronunciation) (b). Tidak dapat mengontrol kecepatan berbicara penutur (c). Tidak dapat mengulangi kembali apa yang sudah didengar (d). Keterbatasan kosa kata pembelajar(e). Kesulitan/kegagalan dalam berkonsentrasi (f). Perbedaan shared knowledge yang menyebabkan perbedaan interpretasi (g). Ketidakmampuan dalam memahami tanda-tanda (signpost words) (h). Keterbatasan mengakses authentic materials dalam pembelajaran (i). Ketiadaan unsur visual yang dapat membantu pemahaman. Di samping masalah-masalah tersebut, ketertarikan siswa terhadap kegiatan maupun keterampilan menyimak ini sendiri juga perlu ditingkatkan, agar konsentrasi mereka dalam kegiatan itu dapat terpelihara. Kelemahan konsentrasi atau kurangnya ketertarikan ini bisa disebabkan antara lain oleh materi pembelajaran yang monoton, strategi pembelajaran yang diterapkan guru yang kurang sesuai dengan minat siswa, atau karena tidak sesuainya tingkat kesulitan bahan dengan kemampuan siswa. Dalam hal ini, peran guru sebagai pengajar atau pengkondisi materi dan suasana belajar memang masih sangat dominan. Bila hal-hal tersebut dapat diperbaiki, maka siswa akan lebih siap dan lebih tertarik untuk belajar.

\subsection{Metode Total Physical Response (TPR) atau Respon Fisik Total}

Total Physical Response (TPR) atau

Respon Fisik Total adalah sebuah metode pengajaran bahasa yang dikembangkan untuk membantu belajar bahasa kedua oleh Prof. Dr. James J. Asher seorang profesor psikologi di San Jose State University California. Berbeda dari metode pengajaran bahasa yang lainnya, metode TPR ini menggunakan perintah untuk membangun koordinasi kemampuan berbahasa dan perilaku. Asher (dalam Richards \& Rodgers, 2003) mengemukakan bahwa kebanyakan struktur gramatikal bahasa target dan ratusan item kosa kata dapat dipelajari dari penggunaan perintah secara terampil oleh instruktur.

Total Pshycal Response (TPR) adalah metode pengajaran bahasa dengan menggunakan gerakan fisik untuk bereaksi terhadap masukan secara lisan dalam rangka untuk mengurangi hambatan dan menurunkan afektif siswa. Menurut Asher, pengucapan langsung pada anak akan merespon kepada fisiknya sebelum mereka mulai untuk menghasilkan respon verbal atau ucapan. TPR lebih menekankan pada gerak tubuh dan instruksi dari guru jadi untuk memantapkan boleh digunakan media gambar-gambar sesuai tema, dan tema yang dipilih pun harus sesuai dengan gerak yang akan dilaksanakan. TPR adalah the comprehension approach atau pendekatan pemahaman yakni metode pendekatan bahasa asing dengan perintah atau instruksi (Larsen \& Freeman, 1986). Richards \& Rodgers (1999) juga berpendapat bahwa TPR merupakan suatu metode pembelajaran bahasa yang disusun pada koordinasi perintah (command), ucapan (speech) dan gerak (action); dan berusaha untuk mengajarkan bahasa melalui aktivitas fisik (motor). Hal ini juga diperkuat oleh Richard (2001) yang juga menyatakan bahwa Total Physical Response atau Respon Fisik Total merupakan metode pengajaran bahasa yang menggunakan kerjasama ucapan dan gerak tubuh yang merupakan usaha untuk mengajarkan bahasa melalui sebuah aktifitas. Metode TPR merupakan metode pembelajaran bahasa yang berhubungan antara koordinasi perintah, ucapan dan gerak. Sehingga seorang guru berusaha mengajarkan bahasa melalui aktifitas fisik. Maka menurut definisi dari para ahli di atas, dapat disimpulkan bahwa metode Total Physical Response adalah sebuah metode pembelajaran bahasa yang menekankan pada koordinasi antara perintah verbal dan aktivitas fisik siswa sehingga dapat memberikan rasa bahagia bagi siswa 
karena mengandung aktivitas gerak tubuh dan tidak akan membuat siswa terutama anak usia dini merasa bosan dalam mempelajari bahasa target.

Menurut Ratminingsih (2017), terdapat beberapa 7 (tujuh) karakteristik dasar dari metode Total Physical Response ini yaitu:

1. Metode ini bertujuan untuk membuat siswa belajar berkomunikasi menggunakan bahasa target dalam situasi yang menyenangkan.

2. Maksud dalam bahasa target diungkapkan melalui perilaku dengam menggunakan imperatif (perintah).

3. Pemahaman siswa terhadap bahasa target sepatutnya dikembangkan sebelum berbicara (mendengarkan terlebih dahulu, kemudian dilanjutkan dengan berbicara).

4. Imperatif (perintah) merupakan alat kebahasaan yang berpengaruh, untuk mengarahkan perilaku siswa.

5. Perasaan suskses dan kecemasan yang rendah memfasilitasi pembelajaran.

6. Koreksi yang diberikan dengan cara yang tidak langsung dan bijaksana.

7. Siswa akan mulai berbicara ketika mereka telah siap.

Menurut Larsen \& Freeman (2000), ada tiga belas aspek di dalam pengajaran metode TPR antara lain: 1) Bahasa target harus disajikan secara utuh, tidak hanya kata demi kata. 2) Pemahaman siswa tentang bahasa target harus dikembangkan sebelum berbicara. 3) Siswa pada awalnya memanggil satu bagian bahasa dengan cepat dengan menggerakkan tubuh mereka. 4) Perintah adalah perangkat linguistik yang kuat dimana guru dapat mengarahkan perilaku siswa. 5) Siswa dapat belajar melalui pengamatan tindakan serta melakukan tindakan sendiri. 6) Sangat penting agar siswa merasa sukses. Perasaan sukses dan rendahnya kecemasan memudahkan pembelajaran. 7) Siswa tidak boleh dihafal rutinitas tetap. 8) Koreksi harus dilakukan dengan cara yang tidak mencolok. 9) Siswa harus mengembangkan fleksibilitas dalam memahami kombinasi baru dari potongan bahasa target. Mereka perlu memahami lebih dari kalimat yang tepat yang digunakan dalam pelatihan. Novelty juga memotivasi. 10) Belajar bahasa lebih efektif bila menyenangkan. 11) Bahasa lisan harus ditekankan dalam bahasa tertulis. 12) Siswa akan mulai berbicara saat mereka siap. 13) Siswa diharapkan membuat kesalahan saat pertama kali mulai berbicara. Guru harus toleran terhadap mereka. Bekerja pada detail bahasa yang bagus harus ditunda sampai siswa menjadi agak mahir.

\subsection{Metode TPR untuk meningkatkan Kemampuan Mendengarkan Bahasa Inggris AUD.}

Menurut Asher (dalam Yamin, 2017) faktor emosi sangat berperan penting dalam pembelajaran bahasa pada anak, artinya belajar bahasa dengan melibatkan permainan dan bergerak yang bisa dikombinasikan dengan bernyanyi atau bercerita akan dapat mengurangi tekanan belajar bahasa seseorang. Dia percaya bahwa keceriaan dalam diri seorang anak (positive mood) akan memberikan dampak yang baik bagi perkembangan bahasa anak.

Penggunaan Metode TPR dalam pengajaran Bahasa Inggris pada anak usia dini memiliki beberapa kelebihan yaitu :

1. Metode ini dapat mengajak anak - anak bergerak dalam proses belajar, yang dapat menciptakan lingkungan pembelajaran yang lebih santai dan nyaman bagi anak - anak.

2. Metode ini membantu ingatan dengan mengaitkan gerakan dengan kata.

3. Metode ini fokus pada kemampuan mendengarkan dan kemudian dapat diikuti dengan membuat perintah.

Di dalam penelitiannya

Wijayatiningsih dan Mulyadi (2014) menyatakan dalam penelitiannya bahwa penerapan model TPR dapat membantu anak usia dini dalam menguasai kosakata sederhana dalam bahasa Inggris beserta artinya dalam bahasa Indonesia. Penerapan model TPR dalam bahasa Inggris untuk anak usia dini cocok diaplikasikan kepada anak - anak TK. Selain itu, Ummah (2017) menemukan bahwa kebanyakan siswa TK di RA. Nurul Hikmah Pamekasan lebih tertarik untuk belajar bahasa Inggris saat guru meminta mereka untuk mempraktikkan 
kosakata bahasa Inggris dengan memberi respon secara fisik. Umumnya anak usia dini lebih memilih untuk belajar bahasa Inggris dengan ungkapan sederhana kemudian meniru apa yang dipraktikkan guru baik verbal maupun non verbal (gerakan). Siswa dalam metode TPR ini memiliki peran utama sebagai listener (pendengar) sekaligus actor (pelaku). Siswa mendengarkan dengan penuh seksama kemudian merespon secara fisik berdasarkan perintah yang diberikan guru baik secara kelompok maupun individu. Berhasil tidaknya penerapan metode TPR untuk mengajarkan bahasa Inggris tidak lepas dari kefasihan guru dalam pengucapan (verbal) bahasa Inggris maupun keaktifan guru dalam mempraktikkan gerakan (movement/action).

Beberapa teknik mengajar dalam metode TPR yang dapat diaplikasikan dalam kegiatan mendengarkan bahasa Inggris untuk anak usia dini yaitu :

\section{A. Imperative Drill}

Imperative Drill merupakan aktivitas utama yang dilakukan guru di dalam kelas dari metode TPR. Dalam aktivitas ini guru memberikan beberapa kalimat perintah sederhana menggunakan Bahasa Inggris dan dilakukan secara berulang - ulang. Latihan ini berguna untuk memperoleh gerakan fisik dan aktivitas dari siswa. Seperti misalnya guru mengatakan kata Please Stand Up sambil memperagakan posisi berdiri dan meminta anak - anak untuk mengikuti gerakan berdiri. Jadi setiap anak mendengarkan kalimat Please Stand Up mereka akan berdiri. Drill untuk jenis kalimat ini dapat diganti dengan kalimat Please Sit Down. Contoh kalimat lain misalnya, touch your nose yang artinya sentuh hidungmu. Saat mengatakan kalimat tersebut, guru juga harus memperagakannya dengan menyentuh hidung dan para siswa juga harus mengikuti gerakan tersebut. Jadi, setiap siswa mendengar kalimat touch your nose maka mereka harus menyentuh hidung mereka. Kalimat lain yang dapat digunakan yaitu touch your ear sambil guru memperagakan untuk menyentuh telinga dan diikuti oleh para siswa. Dengan melakukan pola kalimat perintah sederhana seperti ini, para siswa akan dilatih kemampuan mendengarkan (listening) sambil berlatih beberapa kosa kata baru (vocabulary).

\section{B. Action Song}

Action Song merupakan kegiatan mendengarkan lagu sambil memperagakannya. Terdapat beberapa tahapan dalam penggunaan teknik ini yaitu :

1. Guru harus menyanyikan atau memperdengarkan lagu satu kali atau dua kali dan para siswa hanya mendengar lagu tersebut sehingga mereka dapat menangkap ritme lagu yang sedang dimainkan.

2. Ulangi lagu tersebut dan diikuti dengan gerakan sesuai dengan lagu yang dimainkan, seperti misalnya lagu tentang parts of the body atau bagian anggota tubuh. Nyanyikan lagunya dengan menyentuh bagian tubuh yang terdapat dalam lirik lagu tersebut.

Lirik lagu Parts of the Body: Head and Shoulders, Knees and Toes, Knees and Toes Head and Shoulders, Knees and Toes, Knees and Toes and

Eyes and ears and mouth and nose Head and Shoulders, Knees and Toes, Knees and Toes

3. Mintalah siswa mengikuti gerakan yang dilakukan oleh guru sambil mengikuti lirik lagu tersebut.

4. Tanyakan pada siswa apakah mereka mengerti dengan kata - kata pada lirik lagu tersebut. Jelaskan pada mereka jika masih ada arti kata yang mereka belum mengerti.

5. Mainkan lagunya kembali dan bersama dengan para siswa nyanyikan sambil peragakan lagu tersebut.

C. Menggunakan Flash Cards (Kartu Kartu Bergambar)

Dalam teknik ini, guru dapat menunjukkan beberapa kartu - kartu bergambar dan siswa mendengarkan serta memperagakan aktivitas seperti yang terdapat dalam gambar. Tahapan - tahapan dalam penggunaan flash cards ini adalah sebagai berikut : 
1. Persiapkan beberapa flash cards yang berisi gambar - gambar dan kata kerja seperti misalnya, walk, run, write, sing, jump, dance, dan lain - lain.

2. Minta para siswa untuk mendengarkan kata - kata yang diucapkan oleh guru sambil memperlihatkan kartu - kartu tersebut.

3. Minta siswa mengartikan arti kata kata yang diucapkan oleh guru dan memperagakannya.

4. Guru menyebutkan kembali kata - kata yang terdapat dalam kartu dan siswa memperagakannya.

5. Guru dapat mempercepat pengucapan kata - kata tersebut untuk mengetes konsentrasi anak - anak saat mendengarkan instruksi berbahasa inggris yang diberikan sesuai dengan kartu bergambar yang ditunjukkan.

\section{PENUTUP}

Berdasarkan pemaparan di atas dapat ditarik kesimpulan bahwa metode TPR merupakan metode yang cocok untuk digunakan dalam pengajaran mendengarkan bahasa Inggris anak usia dini. Hal ini dapat dilihat dari karakter anak usia dini dalam memahami bahasa asing, pola pembelajaran mendengarkan dalam Bahasa Inggris, dan kelebihan - kelebihan dari metode Total Physical Response (TPR). Metode TPR sangat cocok dengan karakter anak karena mereka suka bergerak berpindah tempat dan merasa cepat bosan jika hanya duduk di atas kursi. Metode TPR dapat memotivasi anak untuk tertarik belajar bahasa Inggris terutama melatih kemampuan mendengar (listening) karena metode ini sangat menghibur mereka dalam mengikuti proses pembelajaran di kelas dan membantu pemahaman anak usia dini terhadap pembelajaran bahasa Inggris secara efektif. Beberapa teknik atau aktivitas yang dapat digunakan untuk melatih kemampuan anak usia dini dalam mendengarkan bahasa Inggris yaitu imperative drill, action songs dan using flash cards.

\section{DAFTAR PUSTAKA}

Brown, H.D. 2001. Teaching by Principles: An Interactive Approach to Language Pedagogy. New York: Addison Wesley Longman, Inc.

Christina, Nuning W .2010. English for Kinder Garden Students. Jakarta. Talenta Media Utama

Harmer, J. 2007. The Practice of English Language Teaching. Harlow, Essex: Pearson Education, Ltd.

Larsen - Freeman, D. 1986. Techniques and Principles in Language Teaching. New York : Oxford University Press.

Larsen-Freeman, D., \& Anderson, M.. 2000. Techniques and principles in language learning. New York: Oxford University Press.

Machackova, Eva. 2009. Teaching Listening. Cambridge: Cambridge UP.

Matondang, Elizabeth Marsaulina. 2005. Menumbuhkan Minat Belajar Bahasa Inggris Anak Usia Dini melalui Lagu dan Gerak. Jakarta : Jurnal Pendidikan Penabur.

Montessori, Dr. Maria. 1991. The discovery of the Child. New York: Ballatine Books

Nunan, D. 2003. The impact of English as a global language on educational policies and practices in the AsiaPacific region. TESOL QUARTERLY Vol. 37, No. 4 p. $589-614$.

Richards, J.C. \& Rodgers, T.S. 2003. Approaches and Methods in Language Teaching. Cambridge : Cambridge University Press.

Richards, J.C. 2008. Teaching Listening and Speaking From Theory to Practice. Cambridge: Cambrdge University Press.

Sad, S. N. 2010. Theory-practice dichotomy: Prospective teachers' evaluations 
about teaching English to young learners. Journal of Language and Linguistic Studies Vol.6, No.2, October

Scott, W. A., \& Ytreberg, L. H. 1990. Teaching English to children. New York: Longman.

Shin, J. K. (2006). Ten helpful ideas for teaching English to young learners. English Teaching Forum, 44 (2), 2-13.

Suhartono.2005. Pengembangan keterampilan bicara anak usia dini. Jakarta: Departemen Pendidikan Nasional.

Yamin, M. 2017. Metode Pembelajaran Bahasa Inggris di Tingkat Dasar. Jurnal Pesona Dasar. Vol. 1 No. 5 April 2017 hal 82-97

Yauri,A. M.(2007).Problematika pengajaran Bahasa Inggris pada madrasah ibtidaiyah di Watampone Sulawesi Selatan. Jurnal Ichsan Gorontalo, 2 (3), pp 1133. 